\title{
HAQIQAH DAN MAJAZ DALAM ALQURAN
}

\author{
Muh. Haris Zubaidillah \\ Dosen STIQ Amuntai \\ Email:hariszub@gmail.com
}

\begin{abstract}
Abstrak
Alquran adalah kitab suci umat Islam yang diturunkan dengan menggunakan bahasa Arab, yang sangat jelas dan terang. Untuk memahami Alquran dengan baik, tentulah seseorang itu harus menguasai bahasa Arab dengan baik pula. Tanpanya Alquran tidak akan mampu dikuasai. Alquran yang terangkum di dalamnya tentang tauhid, syari at, akhlak, dan sebagainya memiliki berbagai macam cara dalam penyampaian makna yang disebut dengan gaya bahasa Alquran. Gaya bahasa yang dimiliki Alquran sangat bervariasi, mulai dari amtsal, qasam, qasas, jadal, khabar, al-insya', tasybih, isti arah, haqiqah, majaz, dan sebagainya. Pada beberapa kalimat pada Alquran, ada yang bermakna khusus, ada pula yang bermakna umum. Namun pada kesempatan ini, penulis akan membahas pokok bahasan dari gaya bahasa al-Qur`an tersebut yaitu Haqiqah dan Majaz.
\end{abstract}

Kata Kunci: Haqiqah, Majaz, Alquran

\section{A. Pendahuluan}

Alquran adalah kitab suci umat Islam yang diturunkan dengan menggunakan bahasa Arab, yang sangat jelas dan terang. "Sesungguhnya Kami menurunkannya berupa Alquran dengan berbahasa Arab agar kalian memahaminya" (QS: Yusuf : 2).

Untuk memahami Alquran dengan baik, tentulah seseorang itu harus menguasai bahasa Arab dengan baik pula. Tanpanya Alquran tidak akan mampu dikuasai.

Alquran yang terangkum di dalamnya tentang tauhid, syari at, akhlak, dan sebagainya memiliki berbagai macam cara dalam penyampaian makna yang disebut dengan gaya bahasa Alquran.

Gaya bahasa yang dimiliki Alquran sangat bervariasi, mulai dari amtsal, qasam, qasas, jadal, khabar, al-insya', tasybih, isti`arah, haqiqah, majaz, dan sebagainya. Pada beberapa kalimat pada Alquran, ada yang bermakna khusus, ada pula yang bermakna umum. Namun pada kesempatan ini, penulis akan membahas pokok bahasan dari gaya bahasa al-Qur`an tersebut yaitu Haqiqah dan Majaz. 


\section{B. Haqiqah}

\section{Pengertian Haqiqah dalam Alquran}

Haqiqah dalam pengertian bahasa, berasal dari bahasa Arab yang artinya nyata, kenyataan, atau asli. Haqiqah dari kata haqqa yang berarti tetap. Sebagai makna subjek (fấil) memiliki arti yang tetap, atau sebagai objek (maf'ūl) yang berarti ditetapkan ${ }^{1}$. Haqiqah berarti adalah sebuah kata yang maknanya asli sebagaimana yang ditetapkan di dalam Alquran.

Haqiqah menurut istilah, adalah kata yang digunakan sebagaimana pertama kali dipergunakan dalam konteks kebahasaan ${ }^{2}$. Menurut Ibnu Subki menyatakan bahwa hakikat adalah lafaz yang digunakan untuk apa lafaz itu ditentukan pada mulanya. Ibnu Qudamah mendefinisikannya sebagai lafaz yang digunakan untuk sasarannya semula. Sementara AlSarkhisi berpendapat bahwa hakikat adalah setiap lafaz yang ditentukan menurut asalnya untuk hal tertentu ${ }^{3}$.

Berdasarkan beberapa istilah diatas, haqiqah adalah sebuah kata dalam ayat Alquran yang digunakan seperti makna semulanya yang telah ditentukan, dan memiliki tujuan tertentu.

\section{Klasifikasi Haqiqah dalam Alquran}

Haqiqah diklasifikasikan ke dalam 2 bentuk, yaitu :

\section{a. Lughawiyyah Wadh iyyah}

Lughawiyyah Wadh iyyah atau biasa disebut dengan alhaqiqah al-lughawiyyah ini adalah kata yang digunakan untuk menunjukkan makna hakiki berdasarkan konteks penggunaan asal kata tersebut. Contohnya kata ar-rajul yang digunakan untuk mennyebut laki-laki dewasa.

\section{b. Lughawiyyah Manqulah}

Lughawiyyah Manqulah ini adalah kata yang digunakan untuk menunjukkan makna hakiki setelah mengalami transformasi atau perubahan makna. Perubahan ini dilakukan oleh ahli bahasa, atau syari'at. Pada bagian ini, terbagi kedalam dua bentuk pula, yaitu :

1) Haqiqah lughawiyyah `urfiyyah

\footnotetext{
${ }^{1}$ Amir Syarifudin, 2008, Ushul Fiqih, Jilit 2, Cet. V, Jakatra: Kencana, h. 345

${ }^{2}$ Hafidz Abdurrahman, 2004, Ulumul Qur'an, Bogor, h.125.

${ }^{3}$ Miftahul Arufin dan A. Faisal Haq. Ushul Fiqih : Kaidah-kaidah Pentapan Hukum Islam, Cet. I, Surabaya: Citra Media, 1997, h. 175
} 
Yaitu kata yang mengalami transformasi makna, dari makna asal penggunaannya kepada makna lain yang kemudian makna tersebut menjadi populer sehingga makna asalnya ditinggalkan.

Contohnya, kata ad-dabbah yang artinya hewan melata, konotasinya bisa manusia dan hewan. Namun kemudian digunakan oleh orang Arab dengan konotasi hewan berkaki empat saja sehingga makna awalnya ditinggalkan.

2) Haqiqah lughawiyyah syar iyyah

Yaitu kata yang mengalami trasformasi makna, dari makna asal kepada makna yang lain yang digunakan oleh pembuat syrìat. Makna yang lain ini berdasarkan dalil syari'at, contohnya shalat, shiyam, al-kufr, dan sebagainya ${ }^{4}$.

Dari beberapa klasifikasi haqiqah tersebut, dapat disimpulkan bahwa haqiqah lughowiyyah wadh iyyah adalah kata yang digunakan sesuai makna hakikinya, sedangkan haqiqah lughowiyyah manqulah adalah makna yang menunjukkan makna asal setelah mengalami transformasi makna, baik secara bahasa, maupun secara syari at.

\section{Signifikansi Haqiqah dalam Alquran}

Setelah memahami haqiqah dari berbagai macam pengertian, dan melihat dari klasifikasinya, haqiqah memiliki signifikansi sebagai berikut :

a. Dengan mempelajari haqiqah, dapat memahami suatu makna kata yang terdapat didalam Alquran dengan baik;

b. Kemudian dapat membedakan, antara kata yang harus diartikan sebagaimana bentuk asalnya, dan mana pula kata yang harus dimaknai setelah mengalami transformasi;

c. Dapat memahami bahwa kata asal yang mengalami transformasi dengan kata lain, memiliki kaitan yang erat dan memiliki maksud tertentu.

\section{Majaz}

Bentuk majaz dalam Alquran, dari bentuk denotatif (haqiqah) ke bentuk metafora (majaz). Menurut Abd al-Qahir al-Jurjani $(471 \mathrm{H})$ majaz adalah kebalikan haqiqah. Sebuah kata yang mengacu kepada makna asal

\footnotetext{
${ }^{4}$ Hafidz Abdurrahman, 2004, Ulumul Qur'an, Bogor, h.125-126
} 
atau makna dasar, tanpa mengundang kemungkinan makna lain disebut dengan haqiqah. Sedangkan majaz adalah sebaliknya, yaitu perpindahan makna dasar ke makna lainnya, atau pelebaran medan makna dari makna dasar karena ada alasan tertentu. Secara teoritik, majaz adalah peralihan makna dari yang leksikal menuju yang literer, atau dari yang denotatif menuju yang konotatif karena ada alasan-alasan tertentu. ${ }^{5}$

\section{Definisi Majaz}

Majaz secara etimologis berasal dari kata bahasa Arab المجاز, bentuk masdar (infinitif) dari kata ج. ${ }^{6}$ Sedangkan secara terminologis para ulama telah banyak mendefinisikannya dengan beberapa ibarah atau perkataan, diantaranya $:^{7}$

a. Ibn Qutaibah mendefinisikannya sebagai bentuk gaya tutur, atau seni bertutur.

b. Sibawayh mendefinisakannya dengan seni bertutur yang memungkinkan terjadinya perluasan makna.

c. Al-Mubarrad mengatakan bahwa majaz merupakan seni bertutur dan berfungsi untuk mengalihkan makna dasar yang sebenarnya.

d. Al-Qaadhy 'Abd al-Jabbaar mengatakan bahwa majaz adalah peralihan makna dari makna dasar atau leksikal ke makna lainnya, yang lebih luas.

e. Ibn Jinny dan Al-Jurjaany menempatkan majaz sebagai lawan dari haqiqat, dan makna haqiqat menurut Ibnu Jinny adalah makna dari setiap kata yang asli, sedangkan majaz adalah sebaliknya, yaitu setiap kata yang maknanya beralih kepada makna lainnya. Sedangkan menurut Al-Jurjaany haqiqah adalah sebuah kata yang mengacu kepada makna asal atau makna dasar, tanpa mengundang kemungkinan makna lain disebut, sedangkan majaz adalah peralihan makna dasar ke makna lainnya, karena alasan tertentu, atau pelebaran medan makna dari makna dasarnya.

\footnotetext{
${ }^{5}$ http://www.referensimakalah.com/2012/12/bentuk-majaz-dalam-al-quran.html

${ }^{6}$ Abdullah As-Sudais, Al-Majaaz 'Inda Al-Usuliyyin Bain Al-Mujiiziin Wa AlMaani'iin,, Al-Maktabah Asy-Syaamilah, hal. 7

${ }^{7}$ http://infopesantren.web.id/ppssnh.malang/cgibin/content.cgi/artikel/dialektika_gaya _bahasa_quran.single.
} 


\section{Klasifikasi Majaz Dalam Alquran}

a. Majaz Fi Al-Mufrad

Majaz fi al-murad adalah majaz yang menggunakan lafadz bukan pada permulaan asal peletakannya. Macam ini disebut juga majaz al-lughawi, dan ia terbagi ke dalam beberapa macam : ${ }^{8}$

1) Al-hadzfu atau an-naqsu, yaitu majaz yang menitikberatkan pada adanya lafadz yang tersembunyi.

Contohnya dalam surat Yusuf: 82

$$
\text { وَاسْأَلِ الْقَرَيَةَ الَّتِي كُنَّا فِيهَا }
$$

Artinya: "Dan tanyalah (penduduk) negeri yang kami berada disitu".

Di dalam ayat ini tersimpan lafadz yang tersembunyi sebelum lafadz القرية (negri), yaitu lafadz أهل (penduduk).

2) Az-Ziyaadah,yaitu majaz yang menitikberatkan pada adanya lafadz atau hurup tambahan.

Contohnya dalam surat Asy-Syuuraa: 11

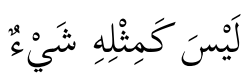

Artinya: "Tidak ada sesuatupun yang serupa dengan Dia"

Sebagian ulama mengatakan bahwa hurup sdi depan lafadz من secara makna muradnya merupakan tambahan.

3) Menyampaikan ungkapan dalam bentuk lafadz plural (jama') namun yang dimaksudkan adalah sebagian saja.

Contohnya dalam surat Al-Baqarah ayat 19:

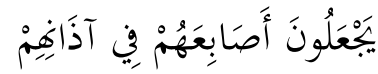

Artinya: "Mereka menyumbat telinganya dengan (anak) jarinya".

Kata أصابع di atas secara leksikal atau makna yang sebenarnya adalah jari-jari. Kiranya mustahil bagi orang-orang munafik Mekkah menyumbat telinganya dengan semua jari karena takut bunyi guntur yang mematikan. Tetapi yang dimaksud أصابع dalam ayat tersebut adalah sebagian dari jarijari, bukan semuanya.

${ }^{8}$ As-Suyuti, Al-Itqan Fi 'Ulum Al-Qur'an hal. 122-128 
4) Menyampaikan ungkapan dalam bentuk lafadz yang merupakan bagian dari suatu nama benda, namun yang dimaksudkan adalah keseluruhannya; bukan sebagiannya.

Contohnya dalam surat Ar-Rahman: 27

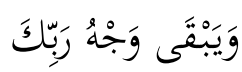

Artinya: "Dan tetap kekal Dzat Tuhanmu".

Lafadz وجه (Wajah) di dalam ayat ini merupakan bagian dari ذات (Dzat) Tuhan, namun di dalam ayat tersebut tidak di ambil makna ذات tetapi dimaknai ذوجه (Dzat).

5) Menyampaikan ungkapan dalam bentuk lafadz khas(khusus), namun yang dimaksudkan adalah 'aam (makna umumnya).

Contohnya dalam surat Al-Munafiqun: 4

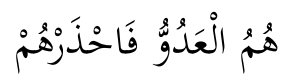

Artinya:"Mereka itulah musuh (yang sebenarnya) maka waspadalah terhadap mereka".

Lafadz العدو (musuh) di dalam ayat tesebut maksudnya adalah الأعداء (semua musuh).

6) Menyampaikan ungkapan dalam bentuk lafadz 'aam(umum), namun yang dimaksudkan adalah khas (makna khususnya).

Contohnya dalam surat Asy-Syuuraa: 5

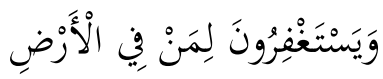

Artinya: "Dan memohonkan ampun bagi orang-orang yang ada di bumi".

Lafadz من (orang) di dalam ayat tersebut di maksudkan khusus bagi المؤمنون (orang-orang yang beriman.

7) Menyampaikan ungkapan dalam bentuk lafadzal'malzuum(yang diharuskan), namun yang dimaksudkan adalah al-laazim (yang mengharuskan).

Contohnya dalam surat Al-An'am: 39

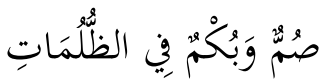

Artinya: "Pekak, bisu dan berada dalam gelap gulita".

Kalimat في الظلمات (dalam kegelapan) di dalam ayat tersebut secara majaz- dari segi asalnya adalah lafadz عمي (buta),

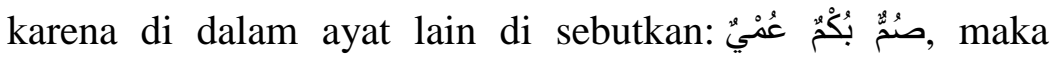


penyebutan في الظلماتdi dalam ayat tersebut dikarenakan kalimat tersebut termasuk dari keharusan orang yang buta, artinya mata orang yang buta pasti merasakan gelap gulita.

8) Menyampaikan ungkapan dalam bentuk lafadzallaazim(yang mengharuskan), namun yang dimaksudkan adalah al-'malzuum (yang diharuskan).

Contohnya dalam surat Al-Maaidah: 112

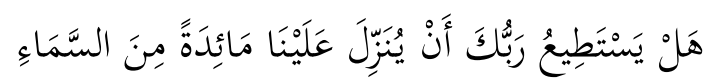

Artinya: "Sanggupkah Tuhanmu menurunkan hidangan dari langit kepada kami?"

Lafadz يسنطيع (sanggup/bisa) di dalam ayat tersebut -secara majaz- dari segi asalnya adalah lafadz يفعل (melakukan), hal ini dikarenakan kesanggupan mengharuskan untuk melakukan.

9) Menyampaikan ungkapan dalam bentuk lafadzalmusabbab (akibat), namun yang dimaksudkan adalah assabab (sebab).

Contohnya dalam surat Al-Mu'min: 13

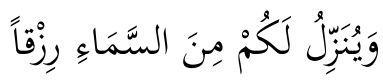

Artinya: "Dan menurunkan untukmu rezki dari langit".

Lafadz رزقا (rizki) di dalam ayat ini merupakan akibat dari turunnya مطر (hujan)

10) Menyampaikan ungkapan dalam bentuk lafadzassabab(sebab), namun yang dimaksudkan adalah almusabbab(akibat).

Contohnya dalam surat Al-Baqarah:

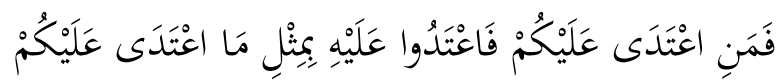

Artinya: "Barangsiapa yang menyerang kamu, maka seranglah ia, seimbang dengan serangannya terhadapmu".

Lafadz اعندوا makna asalnya adalah "Lakukanlah kezaliman" Makna ini tidak bisa dipakaikan karena bertentangan dengan ajaran Islam, yang melarang dari berbuat zalim. Jika kita artikan dengan makna majaz, bisa dipahami bahwa kata اعندوا merupakan sebab dari makna yang dimaksud, 
karena kezaliman merupakan penyebab adanya جزاء (balasan). Jadi makna dari اعتدو adalah "Balaslah".

11) Menamakan sesuatu dengan nama yang biasa disebutkan setelah ia mengalami proses tertentu.

Contohnya dalam surat Yusuf: 36

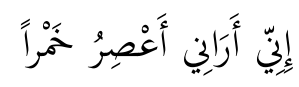

Artinya: "Sesungguhnya aku bermimpi, bahwa aku memeras anggur".

Lafadz خمر (arak) yang di sebutkan di dalam ayat ini adalah nama minuman yang di buat dari perasan عنب (anggur).

12) Menyampaikan ungkapan dalam bentuk lafadzalhal(keadaan), namun maksudnya adalah al-mahal (tempat) yang keadaannya seperti yang di ungkapkan tersebut).

Contohnya dalam surat Ali Imron: 107

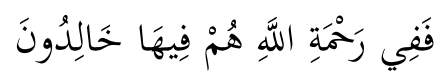

Artinya: "Maka mereka berada dalam rahmat Allah (surga); mereka kekal di dalamnya".

Lafadz رحمة الله (rahmat Allah) di dalam ayat ini, maksudnya adalah الجنة (surga), hal ini karena keadaan surga penuh dengan rahmat Allah.

13) Menyampaikan ungkapan dalam bentuk lafadzalmahal(tempat), namun maksudnya adalah alhal (keadaannya).

Contohnya dalam surat Al-'Alaq: 17

$$
\text { فَلْيَنْعُ نَادِيَهُ }
$$

Artinya: "Maka biarlah dia memanggil golongannya (untuk menolongnya)".

Lafadz نادية adalah nama suatu tempat, dan yang di maksudkan di dalam ayat ini adalah penduduk yang mendiami tempat tersebut.

Menamakan sesuatu dengan nama alatnya.

Contohnya dalam surat Ibrahim: 4

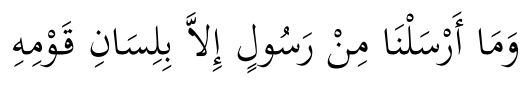


Artinya: "Kami tidak mengutus seorang rasulpun, melainkan dengan bahasa kaumnya".

Lafadz لسان (lisan) di dalam ayat ini merupakan alat untuk melafalkan bahasa, oleh karena itu lafadz tersebut di maknai secara majaz, yaitu bahasa.

14) Menamakan sesuatu dengan nama kebalikannya atau mengungkapkan suatu lafadz yang biasa di gunakan untuk sesuatu kebalikannya.

Contohnya dalam surat Al-Insyiqaaq: 24

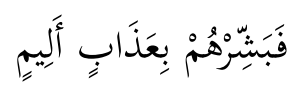

Artinya: "Maka beri kabar gembiralah mereka dengan azab yang pedih".

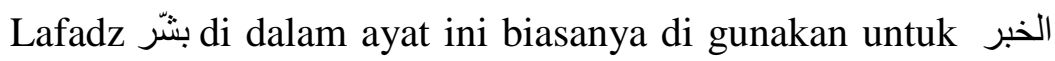
السار (kabar/berita yang menyenangkan/menggembirakan), namun di dalam ayat tersebut di gunakan untuk kabar berita yang tidak menyenangkan sekali, yaitu عذاب أليم (azab yang pedih).

15) Mengidhafahkan atau menghubungkan fi'il (kata kerja) kepada sesuatu yang tidak biasanya di hubungkan dengannya. Contohnya dalam surat Al-Kahfi: 77

$$
\text { فَوَجَدَا فِيهَا ِِدَاراً يُرِيدُ أَنْ يَنْفَضَّ فَأَقَامَهُ }
$$

Artinya: "Kemudian keduanya mendapatkan dalam negeri itu dinding rumah yang hampir roboh, maka (Khidhr) menegakkan dinding itu".

Fi'il يريد (ingin) di dalam ayat ini biasanya di hubungkan dengan جيد الحي (makhluk hidup), sedangkan di dalam ayat ini di hubungkan dengan lafadz جدار (dinding).

16) Menyampaikan ungkapan tentang sesuatu dengan fi'il (kata kerja), namun maksudnya adalah dari segi kedekatan makna fi'il tersebut terhadapnya atau dari segi kemulyaannya atau keinginannya.

Contohnya dalam surat An-Nahl: 61 dan Al-Maaidah: 6

$$
\text { فَاِذَا جَاءَ أَجَلُهُمْ لَا يَسْتَأْخِرُونَ سَاعَة وَلَا يَسْتَقْدِمُونَ }
$$


Artinya: "Maka apabila telah tiba waktunya (yang ditentukan) bagi mereka, tidaklah mereka dapat mengundurkannya barang sesaatpun dan tidak (pula) mendahulukannya".

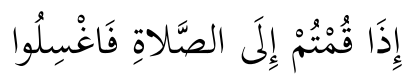

Artinya: "Apabila kamu hendak mengerjakan shalat, maka basuhlah.."

Fi"il (telah tiba) yang di kaitkan dengan lafadz أجل (saat قرب kematian) di dalam ayat pertama maksudnya مجيئه (mendekati tibanya saat kematian). Dan fi'il قمته (kalian mengerjakan) yang di hubungkan dengan lafadz الصلاة (shalat) di dalam ayat kedua maksudnya أردنم القيام (kalian ingin mengerjakan).

17) Menempatkan dua lafadz secara terbalik.

Contohnya dalam surat Ar-Ru'd: 38

$$
\text { لِكُلِّ أَجَلِ كَتَابٌُ }
$$

Artinya: "Bagi tiap-tiap masa ada Kitab (yang tertentu)".

Lafadz كتاب (kitab) seyogyanya di dahulukan dan lafadz أجل (masa akhir) di akhirkan, yakni لكل كتاب أجل (bagi tiap-tiap kitab ada masa akhirnya).

18) Menempatkan suatu shighah (bentuk suatu lafadz) pada kedudukan shighah lain.

Contohnya dalam surat Al-Baqarah: 255

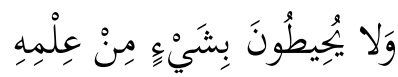

Artinya: "Dan mereka tidak mengetahui apa-apa dari ilmu Allah".

عafadz (ilmu) di dalam ayat ini bershighah مصدر (kata dasar), sedangkan yang seyogyanya adalah shighah المفعول(kata kerja transitif) dari lafadz tersebut, yakni: معلوم (yang di ketahui), sehingga seyogyanya ayat tersebut bermakna:'Dan mereka tidak mengetahui apa-apa yang diketahui oleh Allah".

19) Menamakan sesuatu dengan nama yang biasa disebutkan sebelumnya. 
Contohnya dalam surat Thaahaa: 74

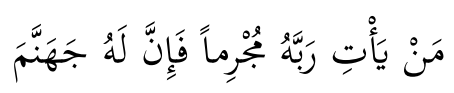

Artinya: "Barangsiapa datang kepada Tuhannya dalam keadaan berdosa, maka sesungguhnya baginya neraka Jahannam".

Di dalam ayat ini orang yang datang kepada Tuhannya pada hari kiamat di namai مجرم (penjahat), hal itu di sesuaikan dengan keadaan dia sewaktu melakukan kejahata/dosa di dunia ini.

\section{b. Majaz Fi At-Tarkiib}

Majaz fi at-tarkiib adalah majaz yang menyandarkan suatu perbuatan atau kesangsian kepada sesuatu yang tidak memiliki originalitas, dikarenakan adanya hubungan keterkaitan antara keduanya. Majaz ini di sebut juga majaz al-aql dan majaz al-isnaad. ${ }^{9}$

Contohnya dalam surat Al-Anfaal: 2

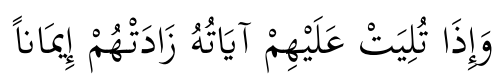

Artinya: "Dan apabila dibacakan ayat-ayat-Nya bertambahlah iman mereka (karenanya)".

Di dalam ayat ini terdapat suatu perbuatan Allah, yaitu الزيادة(penambahan), yang di sandarkan kepada الآيات (ayatayat), hal ini karena dengan dibacakannya ayat-ayat tersebut menjadi sebab bertambahnya keimanan mereka.

Majaz ini terbagi ke dalam empat macam, yaitu sbb:

1) Penyandaran yang kedua sisnya adalah haqiqat (makna asli).

Contohnya dalam surat Az-Zalzalah: 2

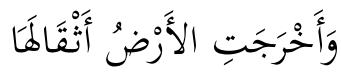

Artinya: "Dan bumi telah mengeluarkan beban-beban berat (yang dikandung) nya".

Penggunaan أخرج lafad (telah mengeluarkan) dan الأرض(bumi) di dalam ayat ini adalah secara haqiqat.

2) Penyandaran yang kedua sisanya adalah majaz.

Contohnya dalam surat Al-Baqarah: 16

${ }^{9}$ As-Suyuti, Al-Itqan .... hal. 120-121. 


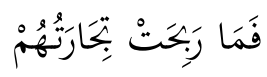

Artinya: "Maka tidaklah beruntung perniagaan mereka".

Penggunaan lafadz ربح (beruntung) dan تجارة (perniagaan) di dalam ayat ini adalah secara majaz.

3) Penyandaran yang sisi pertamanya haqiqat dan sisi lainya majaz.

Contohnya dalam surat Ar-Ruum: 35

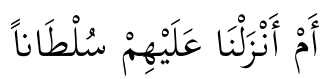

Artinya: "Atau pernahkah Kami menurunkan kepada mereka keterangan".

Penggunaan lafadz أنزل (telah menurunkan) di dalam ayat ini adalah secara haqiqat, sedangkan penggunaan lafadz سلطان(kekuasaan) adalah secara majaz sehingga ia di maknai برهان(dalil/keterangan).

4) Penyandaran yang sisi pertamany majaz dan sisi lainya haqiqat.

Contohnya dalam surat Al-Ma'aarij: 15-17

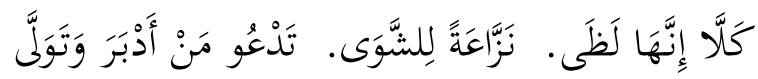

Artinya: "Sekali-kali tidak dapat, sesungguhnya neraka itu adalah api yang bergolak, yang mengelupas kulit kepala, yang memanggil orang yang membelakang dan yang berpaling (dari agama)".

Penggunaan lafadz ندعو (memanggil) di dalam ayat ini adalah secara majaz karena di sandarkan kepada lafadz النار (api neraka).

\section{Signifikasi Majaz}

Diantara faedah-faedah penggunaan majaz adalah sebagai berikut $:{ }^{10}$

a. Al-iijaz yakni memperingkas suatu kalimat atau ungkapan.

b. Memperluas lafadz, dimana seandainya suatu lafadz tidak dimajazkan maka setiap makna hanya memiliki satu komposisi.

c. Menampilkan suatu makna dalam suatu gambaran yang dalam dan dekat kepada akal fikiran. 


\section{Kesimpulan dan Saran}

Haqiqah adalah sebuah kata dalam ayat Alquran yang digunakan seperti makna semulanya yang telah ditentukan, dan memiliki tujuan tertentu. Haqiqah diklasifikasikan ke dalam 2 bentuk, yaitu : Haqiqah Lughawiyyah Wadh iyyah dan Haqiqah Lughawiyyah Manqulah (Pada bagian ini, terbagi kedalam dua bentuk pula, yaitu Haqiqah lughawiyyah unfiyyah dan Haqiqah lughawiyyah syar’iyyah). Haqiqah memiliki signifikansi di antaranya : Dengan mempelajari haqiqah, dapat memahami suatu makna kata yang terdapat didalam Alquran dengan baik, Kemudian dapat membedakan, antara kata yang harus diartikan sebagaimana bentuk asalnya, dan mana pula kata yang harus dimaknai setelah mengalami transformasi, Dapat memahami bahwa kata asal yang mengalami transformasi dengan kata lain, memiliki kaitan yang erat dan memiliki maksud tertentu.

Majaz adalah peralihan makna dasar ke makna lainnya, karena alasan tertentu, atau pelebaran medan makna dari makna dasarnya. Majaz ada dua, yaitu: Majaz Mufrad dan Majaz Fi at-Tarkib. Diantara faedah-faedah penggunaan majaz adalah : Al-iijaz yakni memperingkas suatu kalimat atau ungkapan, Memperluas lafadz, dimana seandainya suatu lafadz tidak dimajazkan maka setiap makna hanya memiliki satu komposisi, Menampilkan suatu makna dalam suatu gambaran yang dalam dan dekat kepada akal fikiran.

Untuk membaca dan menafsirkan apa yang dikehendai oleh Allah, seorang mufassir dituntut untuk menguasai makna-makna dalam Alquran, baik makna haqiqi dan majazi. Oleh karena itu, sangat dianjurkan bagi para penuntut ilmu agar mempelajari ilmu ini dengan baik.

\section{E. Daftar Pustaka}

Abdurrahman, Hafidz. 2004. Ulumul Qur'an. Bogor.

Al-Ibyaarii, Ibrahim, $1405 \mathrm{H}$, Al-Mausuu'ah al-Qur'aaniyah, Muassasah Sijil Al-Arab.

Al-Qoi'ii, Dr. Muhammad Abdulmun'im, 1996, Al-Ashlaan Fi 'Ulum Alquran, , Dar Al-Mun'im Al-Qoi'ii,.

Arufin, Miftahul dan A. Faisal Haq. 1997. Ushul Fiqih : Kaidah-kaidah Pentapan Hukum Islam. Cet. I. Surabaya: Citra Media. 
Ashari, S.Pd.I, Rahmat, Al-Haqiqah Dan Al-Majaz Dalam Alquran, (24 Juli 2013), http://rahmadashariuinsuska.blogspot.co.id, diunduh pada tanggal 9 Okotober 2015.

As-Sudais, Abdullah, Al-Majaaz 'Inda Al-Usuliyyin Bain Al-Mujiiziin Wa AlMaani'iin, Al-Maktabah Asy-Syaamilah.

As-Suhuud, Ali, Al-Khulaashah Fi 'Ilmu Al-Balaaghah, Al-Maktabah AsySyaamilah.

As-Suyuti, Al-Itqan Fi 'Ulum Alquran, Al-Maktabah Asy-Syaamilah.

Halimi, Majazi (Tasybih, Istiarah, Dan Kinayah), http://pascasarjanahalimi.blogspot.co.id, diunduh pada tanggal 9 Okotober 2015.

Syarifudin, Amir. 2008. Ushul Fiqih. Jilit 2. Cet. V. Jakatra: Kencana. 